\title{
RESEARCH FOR MARKETING
}


Other books by Michael J. Baker include

MARKETING: THEORY AND PRACTICE MARKETING STRATEGY AND MANAGEMENT MARKETING: AN INTRODUCTORY TEXT 


\section{RESEARCH FOR MARKETING}

Michael J. Baker

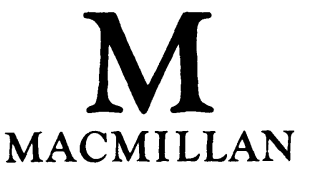


(C) Michael J. Baker 1991

All rights reserved. No reproduction, copy or transmission of this publication may be made without written permission.

No paragraph of this publication may be reproduced, copied or transmitted save with written permission or in accordance with the provisions of the Copyright, Designs and Patents Act 1988, or under the terms of any licence permitting limited copying issued by the Copyright Licensing Agency, 33-4 Alfred Place, London WCIE 7DP.

Any person who does any unauthorised act in relation to this publication may be liable to criminal prosecution and civil claims for damages.

First published 1991

Published by

MACMILLAN EDUCATION LTD

Houndmills, Basingstoke, Hampshire RG21 2XS

and London

Companies and representatives

throughout the world

Edited and typeset by Povey/Edmondson

Okehampton and Rochdale, England

British Library Cataloguing in Publication Data

Baker, Michael J. (Michael John), 1935-

Research for marketing

1. Marketing. Research

I. Title

658.83

ISBN 978-0-333-47021-3 ISBN 978-1-349-21230-9 (eBook)

DOI 10.1007/978-1-349-21230-9 


\section{Contents}

List of figures $\quad \mathbf{x}$

List of tables $\quad \mathrm{xi}$

Preface xiii

1 'Look before you leap'

Introduction $I$

Environmental turbulence

1

The rediscovery of marketing

What now?

7

The function of marketing research

8

The marketing decision 10

Definitions 12

The scope of marketing research

Classification of marketing research

The use of marketing research

Summary 20

2 Problem recognition and specification

Introduction 23

Marketing decision making 24

The need for marketing decisions

Steps in the research process 30

Quantitative or qualitative research?

Problem identification 35

The classification of market problems

Modelling the marketing research process

Summary

40

3 What do we know?

41

Introduction 41

The uses of secondary research

The advantages and disadvantages of secondary research

Rules for desk research 
External sources 52

Government official sources 52

Universities and non-profit organisations

Trade associations 55

Commercial research organisations

Summary $\quad 58$

4 What do we need to know?

60

Introduction

60

Defining and developing a research brief

60

What is information worth? 66

In-house or bought-in?

70

Selecting a market research agency

Summary

74

5 Developing a research design

75

Introduction 75

The scientific approach to problem solving

Observation

78

Experimentation

80

Survey research

84

The purpose of survey research 86

Advantages and disadvantages of survey research

Issues and topics suited to surveys

89

Qualitative research methodology

92

Cross-sectional and longitudinal studies

What is it? 95

Summary 97

6 Sampling $\quad 100$

Introduction $\quad 100$

The basis of sampling

100

Sampling techniques $\quad 103$

Random samples $\quad 104$

Stratified samples $\quad 105$

Non-probability based or purposive samples

Quota sampling 109

Planning a sample survey $\quad 114$

Summary $\quad 117$

Appendix 1 Technical aspects of sampling

Introduction

118

The basis of sampling

118

Estimating sample size

Appendix 2 Technical report

The study

126

Development work

The pilot study

The sample 
Fieldwork $\quad 127$

The questionnaire $\quad 128$

Regional oversampling

7 Data collection

132

Introduction 132

Question design 132

Question phraseology

Attitude measurement and scaling

Thurstone scales

146

Likert scales

147

Verbal frequency scales

The semantic differential

Questionnaire design

Piloting the questionnaire

Summary

157

8 Data collection methods

159

Introduction $\quad 159$

Interviewing 159

Type of respondent

Type of interview

Unstructured interviews

Group discussions

Advantages and disadvantages

Interviewer guide

171

Semi-structured interviews

Structured interviews

Questionnaire completion

General points

Routing 184

Coding of answers

Probing

188

Show cards $\quad 195$

Scales $\quad 196$

Tick start $\quad 198$

Summary 199

Interviewer selection and control

Telephone surveys

203

Mail surveys 204

Drop and collect surveys

Summary

207

9 Data interpretation

Introduction 209

Data interpretation

Confidence limits and statistical significance

Descriptive statistics 
Inferential statistics

223

Cross-tabulation 225

Analysis of variance (ANOVA)

Correlation 230

Regression analysis

232

234

Multiple regression

Principal components analysis (PCA)

Multiple discriminant analysis (MDA)

Conjoint measurement (CM)

The automatic interaction detector (AID)

Factor analysis $\quad 238$

Cluster analysis $\quad 245$

Multidimensional scaling (MDS)

Conclusion 249

10 Report presentation 251

Introduction 251

Report content Introduction

Method 256

Results 256

Discussion

257

Conclusions

259

Organisation of the written report

Presentation of the written report

Evaluating research reports

11 Syndicated market research services Introduction 267

Syndicated market research 267

Trade research 269

Retail and wholesale audits

Invoice analysis 272

Distribution checks

Price checks 274

Feature checks

Panel research 274

Home audit

Diary method 275 Television viewing panels Analysing panel data

Hall tests

278

Omnibus surveys 280

Benefits and limitations 
Limitations of syndicated research services

Summary 284

12 Information technology and marketing research

Introduction 286

Applications of information technology

287

The Research Machine

291

Use of IT

306

13 Marketing information systems

308

Introduction 308

A systems approach to marketing management MIS defined 312

Marketing research and the MIS 314

Organisational structure and the MIS 316 Summary 317

Questions for discussion 318

Index $\quad 325$ 


\section{List of figures}

2.1 Successive focusing 29

2.2 The research cycle 31

2.3 The market research process 39

5.1 The cycle of scientific research $\quad 77$

6.1 Sample interlocking quota sheet 111

6.2 Sample parallel quota sheet 112

6A.1 The Gaussian or normal distribution 120

6A.2 Areas in two tails of the normal curve 121

6A.3 95\% confidence limits 131

7.1 Annual purchase concentration in 18 product categories $\quad 150$

7.2 A semantic scale 152

9.1 Furniture purchases in the past five years 218

9.2 Furniture purchases in the past five years (rank order) 219

9.3 (a) Positive skewness. (b) Negative skewness 222

9.4 (a) No correlation. (b) High positive correlation. (c) High negative correlation 230

9.5 AID analysis of airline usage decisions 238

10.1a Data for profile and summation analysis of the student motivations

10.1b Goals of postgraduate study in management

10.2 Comparison of summated means 260

12.1 Life-cycles in methods of copying 287

12.2 The Research Machine - diagram of major modules

12.3 The Research Machine - example questionnaire 297

13.1 Mead Johnson's marketing intelligence system 310 


\section{List of tables}

1.1 Conduct of marketing research related to product

1.2 The use of a market research agency

19

1.3 Method or source of market research employed

2.1 Factors determining the value of information

2.2 Hierarchy-of-effects models 27

2.3 Qualitative versus quantitative research

3.I Steps in evaluating a company 44

3.2 Sequence of steps in a secondary data search

3.3 How to get started 50

3.4 Key data contents page 54

3.5 Strathclyde University's marketing information leaflet

4.1 Checklist to guide a researcher when taking a brief

4.2 Decision pay-off table 69

5.1 A taxonomy of surveys 87

6.1 Sampling techniques 103

6A.I Flight delays frequency table 119

6A.2 Values for the the area of the normal curve

6A.3 Factors determining sample size 125

6A.4 Response rates for NCC questionnaire

6A.5 Regional oversampling 129

7.1 Issues in question phrasing

7.2 Complex and simple words

7.3 Sources of response bias

7.4 Profile analysis of two airlines

7.5 Frequency of behaviour

8.1 Advantages of group discussion

8.2 Interview guide 172

8.3 Semi-structured interview guide

8.4 Relative advantages and disadvantages of survey methods

9.1 Furniture purchases in the past five years

9.2 Furniture purchases in the past five years (rank order)

9.3 Tool selection for descriptive statistics

220

9.4 Furniture purchases in the past five years

9.5 Statistical measures of association 
xii List of tables

9.6 Intentions to subscribe to Cable TV

227

9.7 Relative attribute importance for three utility segments

9.8 Factors underlying design success 240

9.9 Major factors underlying design success

12.1 An IT applications framework 290

12.2 Consolidated brand awareness 299

12.3 Number of bars eaten per week 300

12.4 Image rating of Carmella bar 301

12.5 Summary of image ratings 302

12.6 Image Strength and Character 303

12.7 The Research Machine - cost justification 304 


\section{Preface}

During the 1980s there emerged a broadly based consensus that success in an increasingly competitive global market-place depends significantly upon organisations being marketing-orientated and customer-driven. Starting with Peters and Waterman's In Search of Excellence in 1980 through to Michael Porter's The Competitive Advantage of Nations in 1990 there has been a continuous stream of managerial best-sellers concerned with the nature and sources of competitive success as a basis for prescribing strategies and courses of action to enable firms to succeed in a climate of accelerating technological and economic change. In content and approach these books have ranged from the rigorously scientific to the managerially anecdotal. But, despite this variation, there is universal agreement that competitive success depends fundamentally upon a clear understanding of the markets in which one wishes to compete and of the customers and competitors that comprise these markets. By contrast, there is also universal agreement that the primary source of failure is an inadequate knowledge and understanding of the market-place.

In light of this universal agreement one might anticipate that the development of a marketing information system (MIS) and extensive investment in marketing research would be a priority. All the evidence indicates the opposite. For example, in Marketing and Competitive Success (1989) Susan Hart and I report the findings of a rigorous survey in which we found that only 42 per cent of the sample firms had an in-house marketing research function and that only 58 per cent ever made use of any marketing research from external agencies. We also found that there was a significant and positive association between the use of marketing research and competitive success. Many similar surveys in the UK, Europe and North America report the same findings. Clearly, there is a need for much more attention to be given to the role of research in developing marketing and corporate strategy.

Research for Marketing is an attempt to cater for the anticipated growth in demand for information an the subject as students and managers recognise its importance as an essential and first element in the formulation of strategy and management of the marketing mix. Now, there are already many excellent 
textbooks available on the subject of marketing research, so why write another one? Quite simply because the majority of available books are concerned with the practice of marketing research and are written from the perspective of the expert who is actually going to carry out the marketing research function. This book is written for those who want an overview of what marketing research is and what it can and cannot do. More particularly, it is written from the perspective of those who may want to commission research and are looking for guidance on how to define their problem and information needs and how to communicate these to a practitioner; how to assess the suitability of alternative research strategies and the precise methods and instruments to be used; how to place a value on the work agreed upon and how to evaluate the quality of the findings. In other words, this book is written for the user of marketing research rather than the doer. Together with Marketing (5th edition, forthcoming) and Marketing Strategy and Management it is intended to provide a basic library for the market manager 


\title{
Dedication
}

This book is dedicated to the many research assistants who, over the years, have played such an important role in my own research for marketing.

\author{
Stephen T. Parkinson \\ Jennifer L. Drayton \\ Anita M. Kennedy \\ Margaret Potts (née Dickie) \\ Caroline Black \\ Susan Hart \\ Gordon Peaston \\ Linda Service \\ Clare Cameron \\ Jennifer Skene
}




\section{Acknowledgements}

The author and publishers wish to thank the following for permission to reproduce copyright material:

Advertising Research Foundation, Inc., New York, for material from Guidelines for the Public Use of Market and Opinion Research, copyright 1981 Advertising Research Foundation, Inc.

Harvard Business School Publishing Division for the illustration 'Mead Johnson's Marketing Intelligence System', from Lee Adler (1967) 'Systems Approach to Marketing', Harvard Business Review, 45(3), May-June, pp. 10518.

Prentice-Hall, Inc., Englewood Cliffs, New Jersey, for a table from David J. Luck and Ronald S. Rubin, Marketing Research, 7th edn, copyright 1987, p. 119. Reprinted by permission of Prentice-Hall, Inc. Englewood Cliffs, New Jersey.

Richard D. Irwin, Inc., Homewood, Illinois, for material from P. L. Alreck and R. B. Settle, The Survey Research Handbook, 1985.

Sage Publications, Inc., California, for the table 'How to Get Started When Searching Published Sources of Secondary Data' from David Stewart (ed.), Secondary Research: Information, Sources and Methods, copyright 1984 by Sage Publications, Inc., reprinted by permission of Sage Publications, Inc.

Every effort has been made to contact all the copyright-holders, but if any have been inadvertently overlooked the publishers will make the necessary arrangements at the earliest opportunity. 